\title{
CARACTERIZAÇÃO HIDROQUÍMICA E HIDROGEOLÓGICA DAS FONTES CÁRSTICAS DAS BACIAS DOS RIOS TUMIRI, ÁGUA COMPRIDA, FERVIDA E DAS ONÇAS - COLOMBO-PR
}

\author{
EDUARDO CHEMAS HINDI*
}

\author{
DISSERTAÇÃO DE MESTRADO - Programa de Pós-Graduação em Geologia - UFPR \\ DATA DE DEFESA: 23/07/99
}

As fontes cársticas tem importância fundamental para o abastecimento de água para consumo doméstico e irrigação nas áreas urbana e rural de Colombo, PR. Apesar dessa importância, não havia sido realizado qualquer estudo para conhecer suas propriedades hidrogeológicas e químicas. Além disso, a explotação do aqüífero cárstico para o abastecimento de água de Curitiba, por poços perfurados nas vizinhanças dessas fontes, vem causando impactos ambientais como subsidências, colapsos de terreno e diminuição ou secamento de fontes. Os objetivos deste estudo são cadastrar, classificar e caracterizar as fontes cársticas das bacias dos rios Fervida, Tumiri, Água Comprida e Onças, em função de suas propriedades hidrogeológicas e hidroquímicas. O aqüífero cárstico que alimenta essas fontes é constituído pelos mármores dolomíticos da Formação Capiru do Grupo Açungui. As rochas carbo-náticas formam os fundos aplainados dos vales sendo limitadas por faixas de filitos e cortadas por diques de diabásio. Os diques representam o controle estrutural para a ocorrência das fontes, interrompendo o fluxo subterrâneo e forçando a emergência de água na superfície. A maior parte das fontes cadastradas são do tipo fervente que formam, geralmente, um pequeno lago, onde a água ao surgir agita a areia do fundo, dando a impressão de estar fervendo. Em menor número, ocorrem fontes de fratura, onde estas são interceptadas por encosta de vale. A recarga do aqüífero é, principalmente, autogênica, ocorrendo pela percolação de águas de chuva através do solo sobrejacente às rochas carbo-náticas. O intervalo entre precipitações e a variação do nível da água medido em poços tubulares, situados em compartimentos não explotados do aqüífero, é de 60 a 90 dias na bacia do rio fervida e 90 a 120 dias na do Tumiri. A diferença desses intervalos se deve à maior espessura de inconsolidados que cobre o aqüífero na bacia do Tumiri. Foram cadastradas 52 fontes, sendo 17 oriundas de filitos ou da cobertura de inconsolidados e 35 do aqüífero cárstico. Destas últimas, foram selecionadas 16 para estudo detalhado das propriedades hidroquímicas e das características de descarga. Foram coletadas 122 amostras de água para análise físico-química no período de abril a novembro/1997 e em março/ 1998. Os resultados dessas análises serviram de base para a classificação geoquímica das águas, para o cálculo dos índices de saturação de calcita e dolomita e para avaliar a qualidade química da água. As águas das fontes são pouco mineralizadas e apresentam grau de dureza variando de moderadamente dura a dura. Segundo a classificação geoquímica por íons dominantes, são águas do tipo bicarbonatadas-magnesianas e, com relação às propriedades físico-químicas, atendem aos padrões de potabilidade estabelecidos na Portaria $N^{\circ} 36 /$ 1990, do Ministério da Saúde. Embora a concentração do íon nitrato esteja abaixo dos limites de potabilidade, ele ocorre em todas as fontes monitoradas. As fontes da bacia do Tumiri apresentam as concentrações mais elevadas de nitrato, cloreto e sódio, o que pode ser indicativo de contaminação por efluentes domésticos. As águas das fontes estão próximas do nível de saturação em calcita e dolomita na maior parte das amostras, passando a saturadas em conseqüência de variações sazonais. De acordo com as propriedades hidráulicas, as fontes apresentam fluxo artesiano, são perenes e, quanto a variabilidade, são variáveis (1), sub-variáveis (9), e constante (1). Com respeito à magnitude de descarga são classificadas em: $4^{\mathrm{a}}(2), 5^{\mathrm{a}}(8)$ e $6^{\mathrm{a}}(1)$. A descarga média das fontes varia de 1 a $25 \mathrm{l} / \mathrm{s}$.

*E-mail: hindi@setuva.geologia.ufpr.br 